\title{
Train of Language, Train of Thought: Notes on an Exophonic Anomaly
}

\author{
ØYVIND RANGØY
}

\begin{abstract}
The creation of poetry with literary value in a non-native language often invites questions about how this is possible to achieve. This question, however, can be turned around: is there something in being an exophonic poet that, rather than being an obstacle, could make the development and maturing of a poetic language possible? Adam Zagajewski writes that ardor, not irony, can be primary building blocks, and about the ideal of being 'in between'. Ben Lerner writes about the sources of Hatred of Poetry and sees poetry as a potential that can never be completely realised. Being between languages causes the reality of language as one of many possibilities to be always present. The result can be construed as a poetic of time and light, but also of a reconciliation at depth warranted by the poetic ethos. Language becomes aware of itself, its autonomy and inherent lack of objectivity, and this becomes less naive and prone to cliches, but this awareness need not spiral into self-dissolving irony. Rather, it may seek to reconcile the possible ways of seeing the world into a new sense of sincerity. It inspires creative and playful use of language, gives heightened awareness of possible metaphors even where the sense of the transferred image is absent within the framework of one language. This has the potential to change perception of language and reality in a way that makes poetry almost possible.
\end{abstract}

Keywords: poetry; poetics; exophony; irony; bilingualism

One important trait of the poetic language - as well as of the conscious human life - is its love for implicit or explicit analogies, expressed as similes, metaphors and other related devices. Whether the metaphor flickers for one moment in an otherwise ordinary sentence or is extended into a novel-length allegory, it constitutes some kind of model, a representation of a system using concepts.

Although a scientific hypothesis can have poetic qualities, the kind of modelmaking at the core of the poetic language is far from being limited to vehicles for expressing testable hypotheses. Rather than seeking the minimalistic clarity of the testable hypotheses, they tend to operate at different levels simultaneously and are appreciated for their beauty and their intuitive meaningfulness. 
One important and perhaps defining trait of human beings is self-awareness. In the spirit of love for analogies the poetic language displays a similar quality. Language becoming aware of itself has the potential of dissolving its meaning, spiralling it into layers of irony, becoming a game of hide and seek. But it also has the potential to leave the meaning and sincerity of the basic utterances intact while introducing new layers of awareness, increasing its depth. Our train of thought has already left the station. As a metaphor for language, the train has already found its place among my personal analogical devices. In English, the train of thought existed as an expression long before steam locomotives, being first attested in 1651, when Thomas Hobbes writes: "By Consequence, or train of thoughts, I understand that succession of one thought to another which is called, to distinguish it from discourse in words, mental discourse. When a man thinketh on anything whatsoever, his next thought after is not altogether so casual as it seems to be. Not every thought to every thought succeeds indifferently." (Hobbes 1651: 18)

I did not know the origin of the expression. However, the age of the quote did not surprise me, intuitively the expression felt so internalised that a living metaphor imagining an actual train in the modern sense felt like something playful, something not already part of the meaning, but present as a potential. However, the fact that English is not my first language may well be part of the reason why I am reflecting on this potential at all.

\section{II}

My book debut as a poet was in a language I learned as an adult. It turned out to be more than a mere experiment: the Betti Alver literary prize for 2019 acknowledged its literary value. From the reception of the work: "Without wishing to make any discount for the book itself, which deserves to be read without this added value - it is an extremely rare occasion that a foreigner creates a true literary work in Estonian.” (Väli 2019)

I thus often am confronted with the (rhetorical) question: how am I able to create literature in a language that is not my mother tongue? And having reflected on this, I am prone to turn the question around: would I have been able to create literature at all, had it not been for the fact that I simultaneously reside inside and outside of the language? Could it be that becoming an exophonic writer is what has made me a published writer at all? In order to address this question, I have to use the kind of introspection that cannot be objective. My honesty in addressing this question depends on the reader accepting this premise: it is to be expected that the following text will be a subjective account. 
Sources cited are therefore to be taken as illustrations or objects of comparison, not as building blocks in an academic treatise.

So, how did I become an exophonic writer? I was born in Norway and learned my first Estonian word at the age of 19 - coincidentally also the title of my collection of poems, Sisikond (Entrails). Firstly, I spent approximately ten years in Estonia, inter alia acquiring an education in Estonian, secondly ten years back in Norway, primarily working in the management of a fish factory whilst also pursuing translation and both personally and professionally maintaining my ties with Estonia and its language. Finally, I returned to Estonia to assume a teaching position at the University of Tartu.

Studying Estonian is not by any means a common education path for a Norwegian. I always viewed translation as an important way of putting the acquired skills and knowledge to use. In 2005, I assisted in translating some poems by Kristiina Ehin, and this assignment led me to acknowledge the fact that I had no idea about what poetry is. I felt insecure, intimidated, scared and also challenged by having to translate something which I felt I did not understand or grasp. Partially, the failure to grasp poetry was also a result of the disconnection of language from my own emotions, something that I have later come to see as not uncommon among men inclined to philosophical reasoning.

The quest to translate poetry challenged me at different levels. First, I used different materials to get an overview of common characteristics of poetry and verse, which mainly increased my confusion. This led me to a Norwegian Internet forum for poetry writing, Diktkammeret, that is still active and which under the supervision of the poet Helge Torvund has functioned as a poetry school for a considerable number of Norwegian poets. My first poem to attract public attention was selected as the poem of the month of that forum. It was about gutting salmon.

From 2011, after moving back to Norway, creative writing became increasingly personally important to me. In addition to the poetry forum, new social media channels provided venues for sharing my poetry outside of the established literary channels. I mainly wrote in Norwegian. In 2016, I attended a seminar for translators of Estonian literature in Käsmu. The explosively multilingual and yet so Estonian atmosphere was one of wonder and inspiration, and I took notes in the form of poetry. This led to an unexpected chain of events, where my attempts to write in Estonian entered into a discourse with Estonian poets, who encouraged me to pursue it seriously. First, this led me to publish Estonian translations of Knut Ødegård's poems, edited by Veronika Kivisilla and published by Igor Kotjuh (Ødegård 2018), and then to the publication of my very own original debut work in 2019, edited and published by Kaur Riismaa (Rangøy 2019). 
Following a TV interview where I touched upon my poetics, a friend gave me the shortest feedback I have received, and still, it felt complete. He simply said: "Credible!"

This occurred to me when I watched how a singer-poet like Leonard Cohen in London in 2008 could capture the audience with a performance like this: "We're so privileged to be able to gather in moments like this when so much of the world is plunged into darkness and chaos. So: Ring the bells that still can ring / Forget your perfect offering / There is a crack in everything / That's how the light gets in." (Cohen 2008)

I watched the video of the performance many times and was touched and moved by it. "I can't run no more with that lawless crowd / while the killers in high places say their prayers out loud." (Cohen 2008) Then, for a split second, as in a glimpse, I saw the performance as hollow. The perceived credibility disappeared and changed the entire situation. Then, it returned, like in Adam Zagajewski's beautiful poem: "the gentle light that strays and vanishes / and returns.” (Zagajewski 2002)

What was this gentle light that vanished and returned in me? What was it in my subjective perception that disappeared when it all seemed hollow, ultimately leaving me with the options of indifference and anger, and then reappeared as renewed faith in the performer's credibility? In one word, ethos, as in Aristotle's On Rhetoric about the modes of persuasion: "The first kind depends on the personal character of the speaker; [...] Persuasion is achieved by the speaker's personal character when the speech is so spoken as to make us think him credible." (Aristotle 350: book 1, part 2)

This perceived quality is distinct from the content of the poem, it is distinct from the technical performance. It is also distinct from the text as pure structure, from the orphaned concept of text following the death of the author. It is not an aspect of the text as a structure, but rather an experienced relationship between souls, where the ability to move and touch listeners (or readers) depends on a sense of sincerity.

What is the source of this gentle light of (potential) credibility in creating and performing poetry? Certainly, con artists and demagogues are able to simulate credibility (or distract the audience from requiring it) with great technical perfection, and the same can supposedly be done in poetry. There is, however, a simpler answer: by being truthful. By this, I mean having integrity in the sense of not isolating the truthfulness to a narrow context, but rather anchoring it to your entire being, or to paraphrase Descartes: I think this, therefore I am. 
Train of Language, Train of Thought: Notes on an Exophonic Anomaly

IV

In 2012, I was still struggling to grasp the concept of poetry. At the same time, I had the unapologetic grandiosity to formulate a manifest that perhaps most of all illustrates my perceived rhetorical position at the time:

1. Reality is concrete creating butterflies.

2. Do not fear the beautiful. It is dangerous and hence needed.

3. Not everything is said. You knew that.

4. The distinction between experience, empathy and lived life is not compulsory.

Revisiting this younger self, I recognise some aspects that have survived in my poetics and represent some kind of stability or core. Perhaps even more of that core, I recognise when reading Adam Zagajewski's essay "A Defense of Ardor" (Zagajewski 2004). A Polish-writing poet who has lived in Poland, France, Germany and the US, Zagajewski describes himself as being a passenger on a submarine with four periscopes, being able to compare the Polish, German, French and English literary landscapes. With the exception of certain tendencies in the Polish poetry, he perceives them all as ironic, sceptical landscapes.

Zagajewski takes issue with this irony: "Too long a stay in the world of irony and doubt awakens in us a yearning for different, more nutritious fare." (Zagajewski 2004: 9) I very much recognise this yearning. Regardless of the actual, objective dominance of irony and scepticism in the contemporary literary environment, of which I am not a competent judge, I have certainly subjectively experienced such dominance as a position that has challenged me: I have thought of it as some kind of default position, so that deviations from it carry the burden of justification.

Since my discovery of poetry, I have been acutely aware of the potential for sincerity to be perceived as cliché or naive. If I say "I love you" to a person I really care for, it is sincere and beautiful. If I present it as a literary work without modifying context, it is a cliché, regardless of my sincerity in writing it. Writing literary text, and certainly poetry, is concerned with avoiding clichés, as every literary language will have exhausted the basic possibilities and require some freshness in ideas, context or style in order to be assigned literary value.

The use of irony is one possible way of avoiding being interpreted as cliché. It introduces levels of meaning and a certain playfulness. The reader is assigned the task of finding the real meaning and intention, and irony can be applied in many layers. Zagajewski ironically notes that irony comes in handy when we don't know what to do. While acknowledging its usefulness as windows and doors, he does not consider it adequate as a primary building block: "Irony 
RANGØY

knocks very useful holes into our walls, but without walls, it could perforate only nothingness." (Zagajewski 2004: 12)

This is thus what he defends: that "only ardor is a primary building block in our literary constructions.” (Zagajewski 2004: 11) True ardor, encompassing passion, enthusiasm, sincerity, is for Zagajewski a way of pursuing what Plato calls metaxu, the being 'in between': between the earth and the heavens, the rational and the mystical, the humanistic and the demonic. It is the sincerity and seriousness that avoids both fanaticism and fundamentalism.

\section{V}

So what is poetry? I will not define it, only mention some perceived properties. Poetry does not exist and still exists. Like mathematics, it is nothing, it is inaccessible and still the models and symbols give us some context. Like maths, it is nothing and the form of everything. And like maths, it is often transferred through symbols that tend to alienate readers not accustomed to the form.

In his essay "The Hatred of Poetry" (Lerner 2016), Ben Lerner tries to circle in the sources of his experience: that poetry is hated and despised from different sides, from poets and non-poets alike, from the traumatic experiences with unintelligible gibberish in school as well as the poet's sense that poetry is failing. In Plato's republic, poetry is denounced as being dangerous and irrational; today, the anger is often directed at poetry's perceived lack of dangerousness.

Poetry, thinks Lerner, is impossible. He introduces the concept of 'virtual poetry'. Poetry is present as a sense of the possibility of something that is never completely achieved in actual verse. Both the best and the worst poetry can tell us something about what poetry is: the best by almost achieving it, and the worst by the distance from the ideal, thus making us see it.

Poetry, then, is not actual songs. "The actual song of my early youth might be eighties synthpop, but the impulse that gives rise to it, I maintain, is Poetry." (Lerner 2016: 82) He describes how during a mediocre outdoor opera performance he happened to see a single firefly slowly flashing around the orchestra, being simultaneously in the time of the performance in Seville - the present tense of art - and in clock time in Santa Fe. "All I ask the haters - and I too, am one - is that they strive to perfect their contempt, even consider bringing it to bear on poems, where it will be deepened, not dispelled, and where, by creating a place for possibility and present absences (like unheard melodies), it might come to resemble love." (Lerner 2016: 85)

In this, Lerner again makes me think of Zagajewski, who discusses his choice of language: "Writing in Polish - but does it finally matter what language 
we write in? Can't any language, properly used, open the road to poetry, the world? The writer ordinarily sits alone with a blank piece of paper or a pale computer screen staring boldly and intently back at him. He's alone although he doesn't write for himself, but for others. Inspired and impeded by tradition, that great tumult of dead voices, he struggles to see into the future, which is always mute. The thoughts he hopes to express seem at times not to be part of any language; they roar within him like another element, alongside air, water and fire." (Zagajewski 2004: 198)

\section{VI}

I have presented Zagajewski and Lerner not as original sources of my poetics, but as examples of my discoveries of others discovering and capturing things I recognise. I am an inventor of the wheel. I once showed my wife how to roll the drum of the washing machine an extra time upon emptying to make sure that all socks have fallen down. She made me realise that I was not the first person in the world to notice this.

What was real, however, was my joy of discovery. This has intrinsic value independent of its novelty to a larger audience: it is the kind of joy that makes the world endurable and happiness possible. It should never be underestimated. There is nothing naive about the joy of such simple discoveries. What may be naive, is overestimating the interest it will have for the general public.

Poetry, for me, should convey something sincere, some emotion or passion intertwined with a thought. Poetry is an entire experience. It should convey what it does in a way that effectively includes the form, the sound, the rhythm as part of the (re)experience. In doing this, both clichés and naivety reduce the value for an audience and increase the experienced distance between intention and form. The experience itself is not the issue: if it is human, it could potentially interest human beings.

My kind of poetry should therefore be conscious about the language, playful, but also sincere and not overuse irony. It should convey something universal, the inside of human experience, in a way that gives a sense of having seen something new - and its form should support this experience of freshness, insight and clarity.

The possibility of writing poetry in a non-native language that is acknowledged as having literary value, returns us to the question: could the creative mastery of a second language be part of what gives the poetry some of its valued characteristics?

I will first give some examples of aspects of my poetic language, and then try to approach the question by perspectives on being between languages. 


\section{VII}

Following Lerner's thought, if real poetry is impossible outside the ideal, virtual domain, examples of verse are but approximations and hints. If so, the difference between original and translation is not measured between the texts, but by comparing their distance from the perceived ideal. I will try to give a hint of my poetry through my own rough translation of the opening poem of Sisikond:

There was a time when vessels came home.

Rolling on waves they came home, the boots of the fathers were big then.

Still the rock slopes are present, steeply plunging from under their heather duvets

dotted with dry yellow grass

down through the black and slippery slopes

where ebb exposes the sea tangle beards

of unshaven adults.

With rollers in their backs they came home

and under the piers were barnacles waving

like angels and tired mothers

in waters flowing and ebbing.

And eyes were seeking and finding,

colourful balls and flags,

floats and nets up on walls and the sweet smoke of diesel.

There was a future in all of this

that wasn't. And still

is the flow coming home, stroking the seaweeds,

as original liquid light

stored in dark places. (Rangøy 2019: Oli aeg, kui laevad tulid koju, my translation)

The poem opens "There was a time". This is key, in the sense that the poem has multiple times, and the opening establishes three of them at once. If there "was a time", it means that it no longer is. However, it also makes an observant reader consciously or unconsciously - keep track of this time together with the time of writing (the moment the poet says "there was a time") and the time of the reading. When "Still the rock slopes are present", this is at the time of writing, and this time is compared with the mythical light of the childhood memories, while the reader also gets an outside view of the poet's time: the time of this comparison. 
The reader watches from her time the poet watching from his time - a third time. But it does not stop there: "There was a future in all of this / that wasn't" establishes a future of the great fisheries, a future where the child experiences being part of a culture and an industry in a time imagined and present inside the 'time that was'. And then, it states the negation of that time, that it wasn't, thus implying that at some point, it became clear that the childhood dreams of becoming a fisherman were not to be fulfilled. The point of this realisation, the change of the imagined future, would thus be a fifth time in the same poem.

The complexity of the presence of all these times will probably not be consciously analysed by the reader. It is, however, a recreation of a common experience, the simultaneous existence of different times in us, as Galadriel says in the film The Lord of the Rings: “...things that were... things that are... and some things... that have not yet come to pass."

The time of the reading is especially interesting because the poem also has a built-in clock that ticks during the reading, regulating the flow and the timed distribution of intensity, supporting the emotion.

These characteristics are not unique to this poem, but serve as an example of the often unnoticed complexity that builds the structure of mirrors that reflect the light that the poem is filled with, light that comes through the recreation of sensing. Because of the times, the reader will be aware that a child is sensing, and this will make it resonate with childhood memories.

The end of the poem even gives a sixth time: the time of darkness, identified as the storage time of the memories. This is a poetics of light and time.

\section{VIII}

As seen, the fact that I had two languages as part of my identity, Norwegian and Estonian, is closely tied to the fact that I started writing poetry at all. Thus, my intimacy with poetry has always been related to more than one language. I have noticed that some of my favorite poets, such as Zagajewski, but also Knut Ødegård, exhibit some of the same: not exophonic writing per se, but a life inside several languages and societies at once, becoming interpreters and ambassadors between different systems.

During summer, I spend considerable time in a hammock. I talked to a Norwegian friend about this and mentioned the suspension berth, or the net swing, as we call it in Estonian. We realised that my mentioning this piece of linguistic trivia was a consequence of becoming conscious of the fact that I actually conceptualise the same physical quilted hammock in two different ways.

In my Norwegian thought, it is a bed or berth, as a function, that is suspended akin to a suspension bridge. In my Estonian thought, it is a swing, 
RANGØY

however, it is made of net, even though it is not, it is quilted. The original net swing is present as some kind of prototype, and the quilted, comfortable material is thus a modification of the original concept. In addition, the Norwegian concept focuses on the hammock's potential for not moving, like a bed, while the Estonian concept focuses on the potential for swinging, more like a cradle. In practice, I will use it in both ways, thus realising some of the potential of the Norwegian concept and some of the potential of the Estonian concept.

Zagajewski mentioned Plato's metaxu, the 'in between' (Zagajewski 2004). I am certainly pursuing this ideal of being between the lofty heights and the plain earth, but poetic practice thus exposes even another way of being 'in between'. I am always between languages. Bilingual life both personally and professionally, the neverending code switching, has created an almost constant state of being present in both languages at once. I will think simultaneously of suspension berths and net swings, and occasionally even of hammocks, when the situation requires it.

\section{IX}

The 'metaxu' of language is not only about words and concepts, however. It is also being between environments. In the quoted poem from Sisikond, the original Estonian text places it inside the Estonian literary tradition, not in the sense of being typical, but in the sense of belonging to it and inviting comparisons with other Estonian works.

The fact of the text placing itself inside the Estonian language and literature does something with what is described. Revisiting the times of the poem: the time of the reader is a distinct Estonian time. It is a time spent inside the Estonian language and very likely in an Estonian landscape. What is described, however, the sensations and memories, are from outside of the Estonian. The impressions, memories, sensations were once conceptualised in Norwegian and then reconceptualised in Estonian. This is not done in order to achieve any literary effect, it's just the way it is.

In another Sisikond poem, "Outside of Language" (Rangøy 2019: Väljaspool keelt, my translation), becoming rooted in another language is compared to a backwards marriage: one becomes two. It poses the question of who I am outside of language - do I even exist there?

Perhaps only as the one who dreams?

In a third Sisikond poem, "Soft Soil", my relationship with the two countries, and their relationship within me, is thematicised: "I come from a land of granite. A land of storms. A land of cliffs and shipwrecks [...] Here, the soil is soft and the stories hard." The poem concludes: "I am at home here, and 
foreign, like I at home am foreign and at home. And from time to time, as in a glimpse behind mountains, the world is the same." (Rangøy 2019: Pehme muld, my translation) There is a yearning in this, a wish for the two worlds to become one.

These are just examples of how the total effect of being between languages is being torn, being confused, being inspired, being in different times and societies at once. It is constantly being "in between". It is thus as if I have two cores, longing to be one. This is a state of interference between the cores, but also the constant pressing question of who I am in all this. In Leonard Cohen's words: And who shall I say is calling?

\section{$\mathrm{X}$}

The interference of languages. The mingling and mangling of concepts from different languages. The constant question of who I am, and where I belong, which is closely tied to the ethos: who am I to say this? And to whom am I saying it? Returning to our starting point, language has become aware of itself. It is a language conscious of the fact that things can be conceptualised in different ways. This dissolves the naive idea of one single possible form.

Being sensitive to conflict, I have always been inclined to reconcile. Reconciling things on the surface is of little use in long-term relationships, because the achieved peace is not sustainable. Reconciliation is still possible, however, on a deeper level.

One of the internal conflicts bothering me has concerned the nature of language - and in a certain sense, it is a conflict that has concerned all of Western civilisation. We are socialised to identify language with reality, and in a certain sense, this is correct. The language that we inhabit is our reality. What happens when this reality is no longer one?

It is not a problem as long as the domains of the different linguistic realities are separate, because we are good at compartmentalising. The constant unease of code switching, however, makes it impossible to be too comfortable in the reality of one language, although the fact that building personal integrity is possible, seems to reconcile something. There is reality in language, but there is also potential outside language: the same dreamer can dream into both languages.

The fact that personal integrity, and a poetic ethos, can be built regardless of surface, even regardless of the concepts, is an insight that renews the sense of being able to say something truthful, thus having ethos, whilst reminding the sayer that truth does not arise from language but from its function in relationships. It is the constant need of reconciliation between two cores longing to be 
representations of the same integrity, the same ethos. There is a me and you in every language. Between us, there is a potential for truth.

There is a poetics of time and light, but also of reconciliation at depth between the metaphysical and the earthbound, rationality and mysticism, stability and inspiration, honesty and grace, the moment and the past. And just as the light from childhood emerges in a new time, there is the realisation that in the end, it is all the same light.

\section{XI}

Thus, the interference between the languages retains a certain plasticity in the language, meaning that it functions as a defence against the petrification of thought. However, the interference also induces a playfulness arising from the fact that language is always seen from the inside and the outside at the same time.

Ben Lerner talks about sources of the hatred of poetry. One such source could be the naive idea of the pure poetic self, the person untouched by other text and thereby producing text untouched by other text: the self-sufficient romantic genius. An opposite and equally naive idea is the death of the author. The text as only text, the irrelevance of the ethos of the author as a consequence of the irrelevance of the author, and the resulting text as something that essentially cannot be experienced as essential. Both these ideas could work to undermine the ethos of the poet.

How does it affect the ethos of the poet to be constantly made aware of the fact that the language used to construct what you are trying to say is not the only possible system, not only in the sense of style, but in the sense of an entire ecosystem, an entire existence, history, society and a complete set of ways of conceptualising the world?

One possible effect is the realisation that there is no real separation of the reflection about language and the use of language itself. This in itself creates layers characteristic of poetry. And it does so without irony, maintaining the freshness of language through a playfulness that depends on the tension between different linguistic worlds. This tension does not require things to be said in complicated ways. It just reminds us of the beauty of the potential for saying it just like this, simply because that is not the only way.

The poetic ethos is not just an aspect, it is the point. I still have something to say because I am saying it with what I am, with who I am, longing for complete identification with the said, the identification between the sayer and the said, whilst keeping it universally open to be experienced by any human being - and 
Train of Language, Train of Thought: Notes on an Exophonic Anomaly

the fact of this being impossible in actual language, the fact of us knowing it is impossible and still putting up the fight, makes it credible.

\section{XII}

This is the twelfth and last wagon. The wagons are connected. The train of thought is approaching a station. "Not every thought to every thought succeeds indifferently", (Hobbes 1651: 18) said Thomas Hobbes.

The train of thought in my poetry is a train of language. This train affects the writing not because the language once was a foreign language, but because I am aware of it being a train. A train moves on rails. Some things are to be expected because the rails of the language decide its course. Becoming aware of the train, however, is becoming aware of it having an inside and an outside.

Language has become aware of itself. It has become aware of being a train, among all the other things it also could be. And it knows about its potential of leaving the meaning and sincerity of the basic utterances intact while introducing new layers of awareness, increasing its depth.

I can enter the train of language, and while it starts moving, I can climb up on the roof of the wagon and perhaps even lean down to see the light from its windows. It's a poetics of time and light. And of being inside and outside of the same language, swinging in the net swing and dreaming in the suspension berth. And sometimes, in the glimpse of a dream, the world is one.

\section{Øyvind Rangøy \\ oyvind.rangoy@ut.ee \\ University of Tartu \\ ESTONIA}

\section{Bibliography}

Aristotle (350). Rhetoric. http://classics.mit.edu/Aristotle/rhetoric.1.i.html (31 May 2020).

Cohen, L. 2008. Anthem. Concert in London, https://www.youtube.com/watch?v= 48AJBXs5dNc (31 May 2020).

Hobbes, T. 1651. Leviathan or The Matter, Forme and Power of a Common Wealth Ecclesiasticall and Civil.

Lerner, B. 2016. The Hatred of Poetry. New York: Farrar, Straus and Giroux.

Rangøy, Ø. 2019. Sisikond. Tallinn: Vihmakass ja kakerdaja.

Väli, K. 2019. Ühtaegu kerge ja raske "Sisikond”. - Areen, https://ekspress.delfi.ee/ areen/uhtaegu-kerge-ja-raske-sisikond?id=88237969 (2 November 2020). 
RANGØY

Zagajewski, A. 2004. A Defense of Ardor. New York: Farrar, Straus and Giroux.

Zagajewski, A. 2002. Try to Praise the Mutilated World. - Without End: New and Selected Poems, Farrar, Straus and Giroux, https://www.poetryfoundation.org/ poems/57095/try-to-praise-the-mutilated-world-56d23a3f28187 (31.05.2020).

Ødegård, K. 2018. Olin imiku nutt varisenud keldris. Tallinn: Kite. 